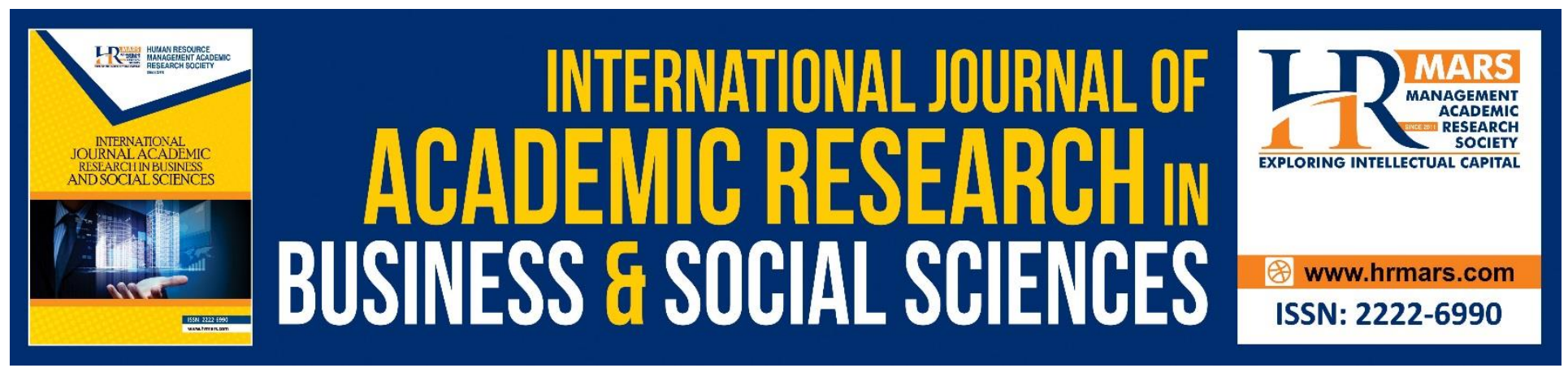

\title{
The Influence of Headmasters' Transformational Leadership on Teachers' Career Development Through Workplace Learning in Malaysian Primary School Clusters
}

Fauzan Salleh, Abdullah Ibrahim, Aizuddin Md Rami

To Link this Article: http://dx.doi.org/10.6007/IJARBSS/v10-i10/7850

DOI:10.6007/IJARBSS/v10-i10/7850

Received: 10 August 2020, Revised: 12 September 2020, Accepted: 27 September 2020

Published Online: 24 October 2020

In-Text Citation: (Salleh, Ibrahim, \& Md Rami, 2020)

To Cite this Article: Salleh, F., Ibrahim, A., \& Md Rami, A. (2020). The Influence of Headmasters' Transformational Leadership on Teachers' Career Development Through Workplace Learning in Malaysian Primary School Clusters. International Journal of Academic Research in Business and Social Sciences. 10(10), 1009-1020.

\section{Copyright: (C) 2020 The Author(s)}

Published by Human Resource Management Academic Research Society (www.hrmars.com)

This article is published under the Creative Commons Attribution (CC BY 4.0) license. Anyone may reproduce, distribute, translate and create derivative works of this article (for both commercial and non-commercial purposes), subject to full attribution to the original publication and authors. The full terms of this license may be seen

at: http://creativecommons.org/licences/by/4.0/legalcode

Vol. 10, No. 10, 2020, Pg. 1009 - 1020

http://hrmars.com/index.php/pages/detail/IJARBSS

JOURNAL HOMEPAGE

Full Terms \& Conditions of access and use can be found at http://hrmars.com/index.php/pages/detail/publication-ethics 


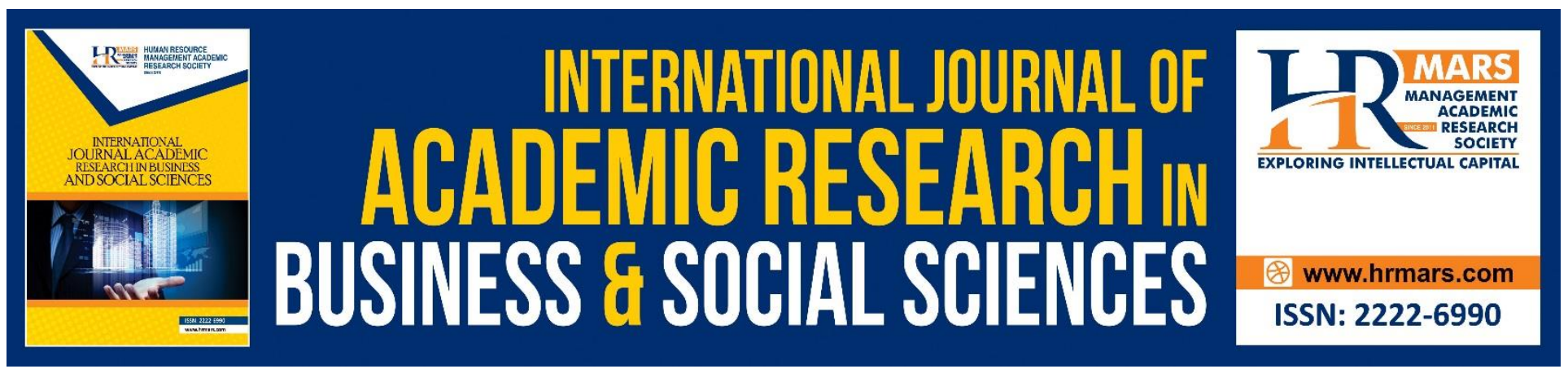

\title{
The Influence of Headmasters' Transformational Leadership on Teachers' Career Development Through Workplace Learning in Malaysian Primary School Clusters
}

\author{
Fauzan Salleh \\ Faculty of Islamic Contemporary Studies, University Sultan Zainal Abidin, 21300, Terengganu, \\ Malaysia \\ Abdullah Ibrahim \\ Center for Fundamental Studies, Universiti Sultan Zainal Abidin, 21300, Terengganu, Malaysia
}

\section{Aizuddin Md Rami}

Faculty of Educational Studies, Universiti Putra Malaysia, 43400, Selangor, Malaysia

Email: abdullahibrahim@unisza.edu.my

\begin{abstract}
This paper presents an insight on the influence of transformational leadership of headmasters on teachers' career development through workplace learning in Malaysian primary school clusters. The study is significant for school headmasters to evaluate the strengths and weaknesses of their leadership practice and make improvements accordingly to ensure effective school management. The study was conducted by using quantitative analytical approach through survey method on 260 respondents who were randomly selected among teachers from 20 primary school clusters in the state of Terengganu to gather their perception of the transformational leadership practice of the headmasters at their school, their individual and collective professional learning, and their professional competency in teaching career.
\end{abstract}

Keywords: Transformational Leadership, Workplace Learning, Career Development

\section{Introduction}

In Malaysia, the national education system has been continuously evolved to cater the needs of the knowledge-based societies and the fast-changing world of the 21st century. In the face of such tremendous changes, school leaders play an important role to transform schools into autonomous, systems-thinking organizations, revolving around professional learning communities that can 
INTERNATIONAL JOURNAL OF ACADEMIC RESEARCH IN BUSINESS AND SOCIAL SCIENCES Vol. 10, No. 10, 2020, E-ISSN: 2222-6990 @ 2020 HRMARS

embrace change and create a high performing learning environment for students and teachers (Moore, 2009a).

The challenges of educational reforms have brought rise to the importance of transformational leadership style which is believed to be more appropriate to sustain with a rapidly changing society compared to the traditional instructional leadership style (Leithwood, 1992; 1994). Transformational leaders provide a mission centred on set directions, a performance centred on professional development, and a culture centred on redesigning the organization (Leithwood, 1994; Leithwood \& Jantzi, 2006; Marks \& Printy, 2003). Literature review has also proven the direct and indirect influence of school leaders' practice of transformational leadership on teachers and students to keep up with the challenges of unpredictable globalized world.

Although there are numoreous positive impacts of tranformational leadership on school administration, there are limited empirical evidence in literature that explains how such leadership practice can benefit teachers' professional growth, especially in the context of Malaysian schools. Therefore, this study was carried out to further explore the influence of tranformational leadership of Malaysian school headmasters on teachers in order to better understand how it can help them to improve the quality of their workplace learning and consequently improve their professional competency.

\section{Issues}

In line with the fast-changing world of the 21st century, school leaders are urged to practice leadership style that is more transformational so that they can embrace the changes and create a high performing learning environment for students and teachers (Bolman \& Deal, 1997; Cheng, 2005; Del Favero, 2006; Moore, 2009a). This is because transformational leadership is believed to be more appropriate for organizations like schools that are constantly under conditions of complex and rapid change (Leithwood \& Jantzi, 1997).

Furthermore, it can help teachers build their capacity to deal with the constant changes and challenges in school management and national education system. Transformational leadership style is also more comprehensive and practical to enhance teachers' commitment and motivation to work toward shared goals and enhance their professional development through four main dimensions which are: Idealized Influence, Intellectual Stimulation, Inspirational Motivation and Individualized Consideration.

In line with the increasing awareness of the importance of transformational leadership in education, the Ministry of Education (MOE) Malaysia has been organizing numerous leadership training courses to encourage school leaders to adopt transformational leadership style for more effective school administration. In addition, the implementation of the Malaysian Education Blueprint 2013-2025 requires placing strong transformational leaders in the most pivotal roles at every level in the national education system. For times, leadership has always been seen as a dynamic factor in organisational success ( Mamat, et al., 2019; Rami, et al., 2019; Aziz, et al., 2020; Rami, et al., 2020a; Rami, et al., 2020b). In educational settings, although the context of school leadership has been rapidly changing, administrators, specifically the principals, still play a decisive role in influencing the motivations of teachers, leading and managing the development of the school.

However, such effort has not yet proven to produce significant results in terms of teachers' professional learning and career development. This issue was also highlighted by Che Sulaiman and Wahab (2017) in their paper that some teachers in Malaysian schools still demonstrate lack of 
INTERNATIONAL JOURNAL OF ACADEMIC RESEARCH IN BUSINESS AND SOCIAL SCIENCES Vol. 10, No. 10, 2020, E-ISSN: 2222-6990 @ 2020 HRMARS

commitment, motivation and self-efficacy and are still reluctant to be more flexible in the face of change in education reforms. This is probably because some school leaders are still not motivated to put more effort to lead the change process in education (Abdullah \& Kassim, 2013). In a research conducted by Jahn (2008), it was also found that the adoption of transformation leadership in cluster schools in Malaysia was very weak. It was suggested that administrators in cluster schools to consider transformational leadership as a fundamental driver in developing positive school culture and to improve the level of self-efficacy among their teachers.

Ishak and Ghani (2013) revealed that there were some school leaders who still did not pay much attention to the holistic development aspect of their teachers. This indicates that most of them still practice traditional leadership style which is not much-ensuring teachers' satisfaction with their jobs. The lack of transformational leadership style among school leaders also results in many teachers still rely on traditional delivery methods and refuse to adopt new teaching practices that are more relevant to current development in education (Kang \& Kim, 2016; Ghavifekr et al., 2014). Moreover, it was found that many teachers had low interest in collaborating with other educational institutions to improve the quality of their teaching and learning practices, and also in participating in conference, short courses, workshops etc. to enhance their knowledge in the field of education. This implies that most school leaders still fall short in motivating teachers to develop their teaching career professionally.

Other than that, there were a number of cases on school leadership had been reported in media for the past few years. In Ketereh for example, about 30 teachers had called for a strike demanding State Education Ministry to replace their school principal as they could no longer deal with the tremendous work pressure (Kosmo, 2018). The recent policy changes in education by the MOE in the past few years had also caused many teachers to opt for early retirement as they could not withstand the increasing challenges in national education system (Sofian \& Nasir, 2010). According to Boon and Hassan (2011), the centralized leadership style which had been practiced by many school leaders might widen the gap between them and their teachers. It could also hamper the school efforts to inculcate knowledge and skill sharing among the members of the school community.

As a solution to the problems stated above, many academic researchers have suggested school leaders to embrace the practice of transformational leadership in order to increase the effectiveness of school management in educational reform efforts (Hallinger, 2003). Previous studies had also shown that transformational leadership can improve teachers' work attitude, teaching quality, job satisfaction, commitment, motivation, job performance and self-identification especially in the challenging era of globalization (Abdullah, 1997; Ashari, 1997; Bakar, 2000; Bolger, 2001; Loy, 2002; Marks \& Printy, 2003; Leithwood et al., 2004; Abdullah, 2005; Castiglia, 2006; Cheng, 2005; Chan et al., 2007; Cheah, 2008; Johan \& Siow, 2008). In addition, transformational school leadership is said to have positive effects on school culture (Barnett \& McCormick, 2004), organizational learning (Silins, Mulford, \& Zarins, 2002), collective teacher efficacy (Ross, 2006), and student engagement (Leithwood et al., 2003).

Nevertheless, there is limited exploration of research on the influence of transformational leadership on teachers, particularly on their workplace learning and career development in the context of Malaysian schools. Most studies on transformational leadership by local researchers are more focused on the level of transformational leadership practices among school headmasters (Musa et al., 2014; Abdullah, 2009; Saad, 2008; Amin, 2010; Jaafar, 2008; Ghazali, 2007), the effects of transformational leadership on teachers' job satisfaction (Majid, 2013; Tahir et al., 2018; Ismail \& 
INTERNATIONAL JOURNAL OF ACADEMIC RESEARCH IN BUSINESS AND SOCIAL SCIENCES Vol. 10, No. 10, 2020, E-ISSN: 2222-6990 @ 2020 HRMARS

Ramli, 2012), the challenges in transformational leadership practices and demographic factors of transformational leaders (Mokhtar, 2002; 2004).

Therefore, this study was carried out to investigate the influence of transformational leadership of the headmasters on teachers' career development through workplace learning in Malaysian primary school clusters. Specifically, this study aimed:

i. to determine the level of transformational leadership among the headmasters

ii. to analyze the influence of transformational leadership on teachers' workplace learning based on Idealized Influence, Intellectual Stimulation, Inspirational Motivation and Individualized Consideration

iii. to analyze the influence of transformational leadership on teachers' career development based on Idealized Influence, Intellectual Stimulation, Inspirational Motivation and Individualized Consideration

iv. to analyze the influence of workplace learning as a mediator between transformational leadership and teachers' career development

The outcome of the study could be useful for school headmasters to understand the importance of transformational leadership for effective school management in the globalization era, and how it can be adopted to develop teachers' professional career through workplace learning. This will also help them to evaluate their current practice and improve their leadership style accordingly so that they are able to lead the change process in educational reforms, encourage the teachers to deliver quality education, increase the level of job satisfaction, motivation and self-efficacy among the teachers, and improve the effectiveness of school management, in line with the objective of Malaysian Education Blueprint 2013-2025 implementation.

\section{Conceptual Framework}

The framework of this study was developed and adapted based on Transformational Leadership Model (Slocum \& Hellriegel, 2007), Learning Organization Dimensions Model (Marsick \& Watkin, 2003), and the Standard of Competency for Malaysian Teachers Framework (Siraj \& Ibrahim, 2012).

Figure 1 illustrates the idea about the research framework which involves 'transformational leadership' as independent variable, 'workplace learning' as a mediating variable and 'career development' as dependent variable. 
INTERNATIONAL JOURNAL OF ACADEMIC RESEARCH IN BUSINESS AND SOCIAL SCIENCES Vol. 10, No. 10, 2020, E-ISSN: 2222-6990 @ 2020 HRMARS

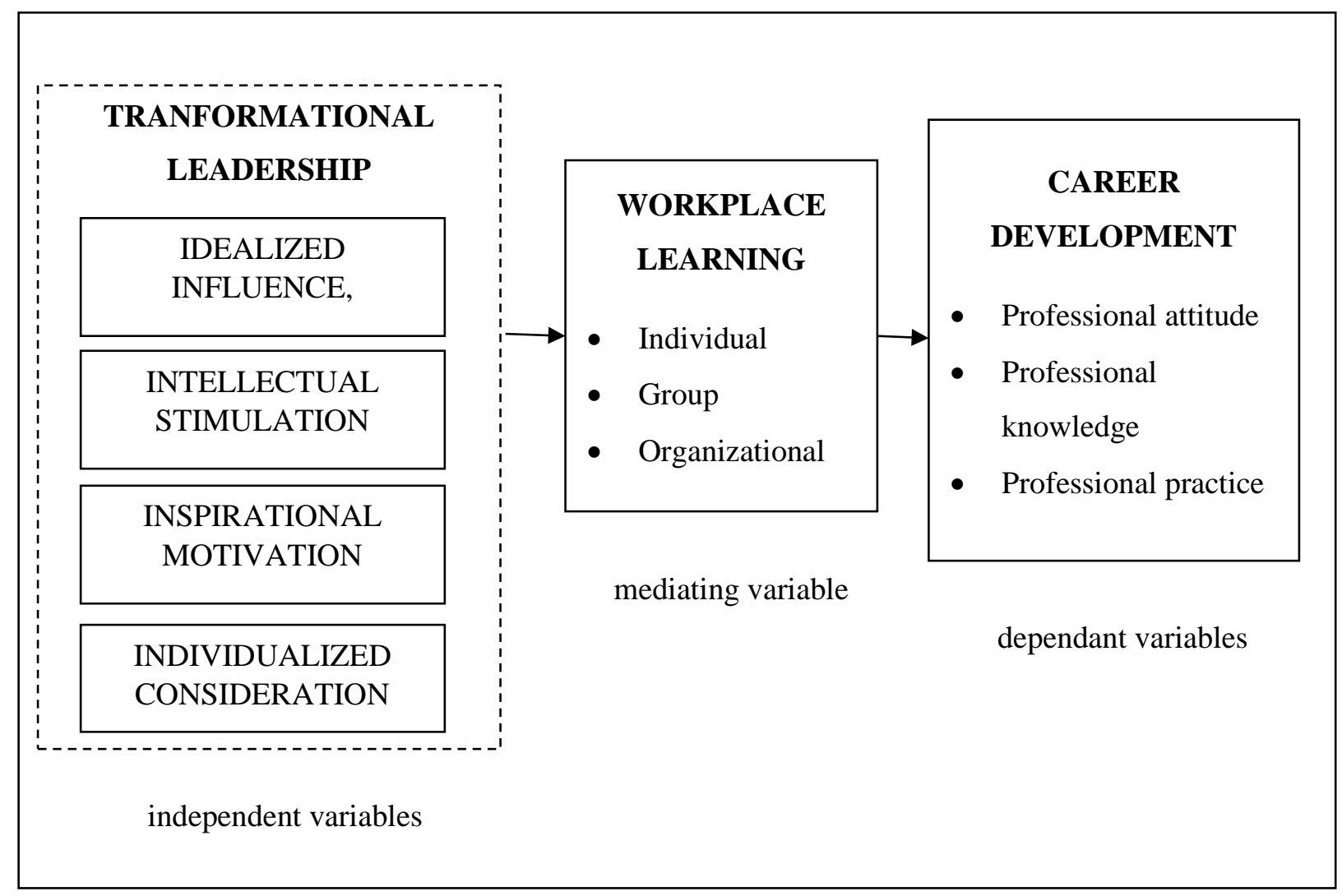

Figure 1. Conceptual framework

\section{Hypothesis}

Several hypotheses were formulated to be used as a guideline to answer the research questions in this study.

- Ho1: There is no significant and positive relationship between Transformational Leadership and Workplace Learning

- Ho2: There is no significant and positive relationship between Workplace Learning and Career Development

- Ho3: There is no significant and positive relationship between Transformational Leadership and Career Development

- Ho4: Workplace Learning has no significant mediating influence on the relationship between Transformational Leadership and Career Development

\section{Methodology}

\section{Operational Definitions}

Transformational leadership in this study refers to the teachers' perception of the ability of the school headmasters to display of conviction and emphasize on trust, commitment, purpose and resolution even in the face of difficult challenges (Bass, 1997); to motivate teachers by communicating high expectations and increasing team spirit and enthusiasm (Northouse, 2001); to empower teachers to be more innovative and propose new ideas (Stone, Russell \& Patterson, 2003); and to always consider every teacher's individual needs, abilities and aspirations (Bass, 1997; Bass \& Bass, 2008). 
INTERNATIONAL JOURNAL OF ACADEMIC RESEARCH IN BUSINESS AND SOCIAL SCIENCES Vol. 10, No. 10, 2020, E-ISSN: 2222-6990 @ 2020 HRMARS

Workplace learning in this study refers to the teachers' perception of their motivation and determination to continuously upgrade their teaching skills and acquire the latest knowledge on teaching practices (Phillips, 2003) through individual and collective professional learning such as collaborative learning activities, self-reflection on current teaching practices, research, participation in academic groups and the application of the current technologies (Ishak, 2012; Watkins \& Marsick, 1993).

Meanwhile, career development in this study refers to the teachers' perception of the standards of their competency and professionalism in performing their teaching job from the aspects of professional attitude, professional knowledge and professional practice.

\section{Research Design}

This study was conducted by using quantitative approach through survey method to gather the teachers' perception of the transformational leadership practice among the headmasters at their school, their professional learning practices and their professional competency in teaching career. Although the target population should consist of all teachers in Malaysian cluster schools, the study population was limited only to all teachers in cluster schools in the state of Terengganu due to time and budget restraint. Out of 805 teachers from 20 primary school clusters in Terengganu, a total of 260 teachers were selected by using cluster sampling to participate as survey respondents.

\section{Research Instrument}

A survey was used as the research instrument in this study. The survey has 70 questions and is divided into four main sections, i.e. Section A (Demographic Profile), Section B (Transformational Leadership), $C$ (workplace learning) and D (career development).

Section A consists five items related to the respondents' demographic profile such as gender, age, academic qualification, race and teaching experience.

Section B consists of 20 items related to four dimensions of transformational leadership which are Idealized Influence, Intellectual Stimulation, Inspirational Motivation and Individualized Consideration. The items were constructed based on Multifactor Leadership Questionnaire (MLQ) by Avolio and Bass (2004) and adapted from other studies such as Ismail and Ramli (2012); Majid (2013) and Slocum and Hellriegel (2007).

Section C consists of 30 items related to three dimensions of workplace learning which are Individual Learning, Group Learning and Organizational Learning based on Marsick and Watkin's (2003) Learning Organization Dimensions Model and adapted from several other studies like Ishak (2012); Ghani et al. (2014).

Section D consists of 15 items related to three dimensions of career development which are professional attitude, professional knowledge and professional practice based on the Standard of Competency for Malaysian Teachers Framework by Siraj and Ibrahim (2012).

Likert scale was used to measure the responses for all items in Section B-D from 1 (strongly disagree) to 5 (strongly agree).

\section{Pilot Study}

The survey procedure was pilot-tested with 100 volunteers in order to refine the data collection plan. The volunteers were selected randomly among teachers from several schools in Terengganu. The 
INTERNATIONAL JOURNAL OF ACADEMIC RESEARCH IN BUSINESS AND SOCIAL SCIENCES Vol. 10, No. 10, 2020, E-ISSN: 2222-6990 @ 2020 HRMARS

main purpose of this test is to ensure the validity and reliability of the research instrument so that modifications on the survey questions could be done before the actual research was carried out.

The data obtained from the pilot study were analyzed using Reliability Analysis to determine the internal consistency of each item in the survey instrument. This would allow the researcher to determine the extent to which the items in the questionnaire are related to each other so that problem items can be identified and thus excluded from the scale. By using Cronbach's alpha model (Cronbach, 1951) in SPSS v25 software, all items in Section B-D were analyzed to the value of Cronbach's Alpha. The Cronbach's alpha is expressed as a correlation coefficient, and its value ranges from 0 to +1 . According to Hair et al. (2006), it was estimated Cronbach's Alpha value of 0.70 or greater level for each item reflects the reliability of the items used or the level of internal consistency among items, thus acceptable for the study

\section{Data Collection}

Once the pilot-testing was completed and the required modification was done, the survey was distributed in person to the selected respondents through emails or by hand. The respondents were given two weeks to complete the survey form and return back to the researcher to proceed with data analysis.

\section{Data Analysis}

The data collected from the survey were then analysed using SPSS v26.0 software utilizing descriptive, correlation and regression analysis.

In descriptive analysis, descriptive statistics (frequency) and aggregate data of mean and standard deviation were used to determine the mean and standard deviation of the respondent's answers in Section B-D in order to understand how the study's variables were perceived by the respondents.

Correlation analysis was carried out to determine the linearity and the strengths of the relationship between each dimension of transformational leadership and the two variables, i.e. workplace learning and career development.

Regression analysis was conducted to describe the relationships between: (1) transformational leadership - workplace learning; (2) transformational leadership - career development; and (3) transformational leadership - workplace learning - career development. This analysis was also conducted to examine whether each independent variable does a very good job in predicting the outcome variable and in what way it impacts the outcome variable, i.e. to test Hypotheses 1-4 in this study.

\section{Conclusion}

This study was conducted to evaluate the influence of transformational leadership practice among the headmasters of primary school custers in Terengganu on teachers' career development through the mediation effect of workplace learning. The evaluation of the practice was measured based on the four dimensions in the Transformational Leadership Model developed by Slocum and Hellriegel (2007) which are Idealized Influence, Intellectual Stimulation, Inspirational Motivation and Individualized Consideration. It was assumed in this study that the transformational leadership of the headmasters would positively influence the teachers' individual and collective professional learning 
INTERNATIONAL JOURNAL OF ACADEMIC RESEARCH IN BUSINESS AND SOCIAL SCIENCES Vol. 10, No. 10, 2020, E-ISSN: 2222-6990 @ 2020 HRMARS

and consequently would enhance their professional competency in teaching practice. However, the findings of the study are yet to be discovered as the data analysis is currently still progressing.

\section{References}

Abdullah, A. G. (2005). Kepimpinan transformasi pengetua dan penggantian kepimpinan sebagai penentu komitmen terhadap organisasi dan perlakuan warga organisasi pendidikan. Jurnal Pendidik dan Pendidikan, 20, 53-68.

Abdullah, A. G. K. (1997). Hubungan persepsi kepemimpinan transformasi dengan kepuasan dan komitmen kerja. Masters in Education, Universiti Sains Malaysia (unpublished).

Abdullah, J. B., \& Kassim, J. M. (2013). Sikap terhadap perubahan dalam kalangan pengetua sekolah negeri Pahang. Presented at Prosiding Seminar Nasional Pengurusan dan Kepimpinan Pendidikan Ke-20, 2013, Institut Aminuddin Baki, Kementerian Pendidikan Malaysia.

Abdullah, M. Z. (2009). Kepimpinan transformasi pengetua dan hubungannya dengan kepuasan kerja guru. Thesis for Master Degree, Universiti Malaya.

Amin, T. M. (2010). Amalan kepemimpinan transformasional pengetua dan keupayaan kepemimpinan guru sekolah menengah di Pahang. Thesis for Master Degree, Universiti Malaya.

Ashari, K. (1997). Hubungan gaya kepimpinan dan gaya kepemimpinan transformasi pengetua dengan kepuasan dan motivasi. Masters in Education, Universiti Sains Malaysia (unpublished).

Aziz, F., Md Rami, A., Razali, F., \& Mahadi, N. (2020). The influence of leadership style towards technology acceptance in organization. International Journal of Advanced Science and Technology, 29(7 Special Issue), 218-225.

Bakar, A. K. A. (2000). Kepemimpinan transformasi: hubungannya dengan kepuasan kerja dan motivasi guru. Thesis for Master Degree, Universiti Utara Malaysia.

Barnett, K., McCormick, J., \& Conners, R. (2001). Transformational leadership in schools - Panacea, placebo or problem? Journal of Educational Administration, 39(1), 24-46.

Bass, B. M., \& Bass, R. (2008). The Bass handbook of leadership, theory, research and managerial applications (4th ed.). New York: Free Press.

Bass, B. M. (1997). Does the transactional-transformational leadership paradigm transcend organizational and national boundaries? American Psychologist, 52, 130-139.

Bolger, R. (2001). The influence of leadership style on teacher job satisfaction. Educational Administration Quarterly, 37(5), 662-683.

Bolman, L. \& Deal, T. (1997). Reframing Organizations: Artistry, Choice, and Leadership. San Francisco, CA: Jossey-Bass.

Boon, Y., \& Hassan, F. (2011). Tahap amalan organisasi pembelajaran di sebuah sekolah menengah daerah Kulaijaya, Johor. Journal of Educational Management, 4, 18 -33.

Castiglia, B. (2006). The impact of changing culture in higher education on the person organization fit, job satisfaction and organizational commitment of college faculty. Academy of Educational Leadership Journal, 10(2), 23-44.

Chan, Y. F., \& Sidhu, G. K. (2007). Stail kepimpinan dan kepuasan kerja guru di kalangan guru sekolah menengah. Presented at The 5th ASEAN Symposium on Educational Management and Leadership (ASEMAL 5), 18-19 August 2007, Legend Hotel, Kuala Lumpur (unpublished).

Che Sulaiman, I. S., \& Wahab, J. A. (2017). Pendekatan Kepimpinan Transformasional Menangani Isu Guru Di Sekolah. Simposium Pendidikan: Perspektif Risalah An-Nur (SPRiN2017). 
INTERNATIONAL JOURNAL OF ACADEMIC RESEARCH IN BUSINESS AND SOCIAL SCIENCES Vol. 10, No. 10, 2020, E-ISSN: 2222-6990 ๑ 2020 HRMARS

Cheah, L. H. (2008). The impact of principal's transformational democratic leadership style on teacher's job satisfaction and commitment. Thesis for Master Degree, Universiti Sains Malaysia.

Cheng, Y. C. (2005). New Paradigm for Re-engineering Education: Globalization, Localization and Individualization. Asia-Pacific Educational Research Association. Netherlands: Springer.

Del Favero, M. (2006). An examination of the relationship between academic discipline and cognitive complexity in academic deans' administrative behavior. Research in Higher Education, 47(3), 281-315.

Ghani, M. F. A., Ishak, R. Siraj, S., Banu, H., \& Crow, G. M. (2014). Keberkesanan amalan organisasi pembelajaran di sebuah sekolah cemerlang di Kuala Terengganu, Terengganu: Satu kajian awal. Jurnal Kurikulum \& Pengajaran Asia Pasifik, 2(3), 22-42.

Ghavifekr, S., Hoon, A. L. S., Ling, H. F., \& Ching, T. M. (2014). Heads of departments as transformational leaders in schools: issues and challenges. Malaysian Online Journal of Educational Management, 2(3).

Ghazali, N. (2007). Tahap amalan kepimpinan transformasi dalam kalangan pengetua Sekolah Menengah Bandar Tangkak. Thesis for Master Degree, Universiti Teknologi Malaysia.

Hallinger, P. (2003). Leading educational change: Reflections on the practice of instructional and transformational leadership. Cambridge Journal of Education, 33(3), 329-351.

Hassan, F. (2018). Pengetua SMK Ketereh ditukar serta merta. In Kosmo Online (19 Julai, 2018). Retrieved from https://www.kosmo.com.my/terkini/pengetua-smk-ketereh-ditukar-sertamerta-1.712154

Ishak, R., \& Ghani, M. F. A. (2013). Amalan pembelajaran kolektif dalam kalangan guru sekolah berprestasi tinggi di Malaysia. Jurnal Kajian Pendidikan, 3(1), 27-34.

Ishak, R. (2012). Profil amalan terbaik organisasi pembelajaran. Thesis for PHD, Universiti Malaya, Kuala Lumpur (unpublished).

Ismail, H., \& Ramli, Z. (2012). Amalan kepimpinan transformasi pengetua dan hubungannya dengan kepuasan kerja guru. Prosiding PERKEM VII, JILID 2 (2012), 1471 - 1478.

Jaafar, S. (2008). Kepemimpinan transformasional pengetua di sebuah sekolah menengah berprestasi tinggi di Hulu Selangor. Thesis for Master Degree, Universiti Malaya.

Jahn, A. M. A. (2008). Budaya Sekolah Cemerlang di Sebuah Sekolah Kluster. Universiti Malaya.

Johan, M. O., \& Siow, S. F. (2011) Hubungan antara stres dengan kepuasan kerja guru penolong kanan di sekolah jenis kebangsaan Cina daerah Kulai, p.1-9 (unpublished).

Kang, M., \& Kim, Y. (2016). A desirable direction for English teachers' in-service training program in the Future, 122, 37-41.

Leithwood, K., \& Jantzi, D. (1997). Explaining variation in teachers' perceptions of principals' leadership: A replication. Journal of Educational Administration, 35(4), 312-31.

Leithwood, K. (1992). The move toward transformational leadership. Educational Leadership, 49(5), 8-13.

Leithwood, K. (1994). Leadership for school restructuring. Educational Administration Quarterly, 30(4), 498-518.

Leithwood, K., \& Jantzi, D. (2006). Transformational school leadership for large-scale reform: Effects on students, teachers and their classroom practices. School Effectiveness and School Improvement, 17(2), 201-227. 
INTERNATIONAL JOURNAL OF ACADEMIC RESEARCH IN BUSINESS AND SOCIAL SCIENCES

Vol. 10, No. 10, 2020, E-ISSN: 2222-6990 @ 2020 HRMARS

Leithwood, K., Louis, K. S., Anderson, S., \& Wahlstrom, K. (2004). How leadership influences student learning. Toronto, ON: CAREI \& OISE.

Leithwood, K., Riedlinger, B., Bauer, S., \& Jantzi, D. (2003). Leadership program effects on student learning: The case of the Greater New Orleans school leadership center. Journal of School Leadership, 13(6), 707-738.

Loy, L. H. (2002) Hubungan kepemimpinan transformasional pengetua dengan kepuasan kerja guru. Thesis for Master Degree, Universiti Putra Malaysia.

Majid, I. N. F. A. (2013). Hubungan gaya kepimpinan transformasional pengetua dengan kepuasan kerja guru di Sekolah Menengah Daerah Pasir Gudang. Thesis for Master Degree, Universiti Teknologi Malaysia.

Marks, H., \& Printy, S. (2003). Principal leadership and school performance: An integration of transformation and instructional leadership. Educational Administration Quarterly, 39(3), 370397.

Marsick, V. J., \& Watkins, K. E. (2003). Demonstrating the value of an organization's learning culture: The Dimensions of Learning Organizations Questionnaire. Advances in Developing Human Resources, 5,132-151.

Mamat, N., Rami, A., Abdullah, R., Amat Simin, M. H., \& Hashim, S. S. (2019). Malay language teaching and learning strategies among orang asli students in Terengganu. International Journal of Recent Technology and Engineering, 8(1C2), 1158-1161.

Mokhtar, Z. (2002). Amalan pengurusan pentadbir akademik universiti: Satu kajian kes. Thesis for PHD, Universiti Kebangsaan Malaysia (unpublished).

Moore, B. (2009a). Emotional intelligence for school administrators: A priority for school reform? American Secondary Education, 37(3), 20-28.

Musa, K., Yusof, H., Yunus, J. N., \& Hamid, S. A. (2014). Kepimpinan transformasional pengetua: Perbandingan antara sekolah menengah awam dan swasta cemerlang. Management Research Journal, 3, 120-139.

Northouse, P. G. (2001). Leadership: Theory and practice (2nd ed.). Thousand Oaks, CA: Sage Publications, Inc.

Phillips, J. (2003). Powerful learning: Creating learning communities in school reform. Journal of Curriculum and Supervision, 18, 240-258.

Rami, A. M., Aziz, F., Razali, F., \& Ibrahim, A. (2020a). Effective local leadership to a successful council in the state of Terengganu, Malaysia. International Journal of Advanced Science and Technology, 29(7 Special Issue), 205-210.

Rami, A. M., Aziz, F., Razali, F., \& Yusof, M. R. (2020b). Leadership and ICTs implementation for rural development. International Journal of Advanced Science and Technology, 29(7 Special Issue), 531-535.

Rami, A. M., Simin, H., Abdullah, R., \& Ibrahim, A. (2019). Community leader in enhancing rural economic growth in state of Terengganu, Malaysia. International Journal of Recent Technology and Engineering, 8(2 Special Issue 11), 680-684.

Ross, J., \& Gray, P. (2006). Transformational leadership and teacher commitment to organizational values: The mediating effects of collective teacher efficiency. School Effectiveness and School Improvement, 17(2), 179-199. 
INTERNATIONAL JOURNAL OF ACADEMIC RESEARCH IN BUSINESS AND SOCIAL SCIENCES

Vol. 10, No. 10, 2020, E-ISSN: 2222-6990 @ 2020 HRMARS

Saad, M. A. (2008). Gaya kepemimpinan transformasional pengetua dan hubungannya dengan kepuasan kerja guru di sebuah sekolah dalam daerah Maran, Pahang. Thesis for Master Degree, Universiti Malaya.

Silins, H., Mulford, B., \& Zarins, S. (2002). Organizational learning and school change. Educational Administration Quarterly, 38(5), 613-642.

Siraj, S., \& Ibrahim, M. S. (2012). Standard Kompetensi Guru Malaysia. Universiti Malaya. Available at http://www.fp.utm.my/ePusatSumber/listseminar/medc2012/pdf/159.pdf

Slocum, J. W., \& Hellriegel, D. (2007). Fundamentals of organizational behavior. USA: Thomson South Western.

Sofian, S., \& Nasir, R. (2010). Kesan kecerdasan emosi ke atas tekanan kerja dan niat berhenti kerja profesion keguruan. Jurnal e-Bangi. 5(1), 53-68.

Stone, A. G., Russell, R. F., \& Patterson, K. (2003). Transformational versus servant leadership - A difference in leader focus. Servant Leadership Roundtable, October 2003.

Tahir, A., Mansor, A., \& Darusalam, G. (2018). Amalan kepimpinan transformasional guru besar dan hubungannya terhadap kepuasan kerja guru sekolah daerah Miri. Presented at the International Conference of Educational Issues, July 5, 2018, Auditorium Utama, Faculty of Education, Universiti Malaya.

Watkins, K. E., \& Marsick, V. J. (1993). Sculpting the Learning Organization. San Francisco, CA: Jossey-Bass. 